\title{
Evaluation of Biological-rhythm Using the Biological Rhythm Interview of Assessment in Neuropsychiatry (BRIAN) in Rheumatoid Arthritis
}

\author{
Romatoid Artritli Hastalarda Biyolojik Ritmin Biyolojik Ritim Değerlendirme Ölçeği \\ (BRIAN) ile Değerlendirilmesi
}

๑ Betül Sargın, ๑ Gülcan Gürer

Adnan Menderes University Faculty of Medicine, Department of Physical Medicine and Rehabilitation and Rheumatology, Aydın, Turkey

\section{Abstract}

Aim: We aimed to evaluate biological rhythm in rheumatoid arthritis (RA) patients using the Biological Rhythms Interview of Assessment in Neuropsychiatry (BRIAN).

Methods: Eighty-five RA patients and 85 healthy controls were included in the study. Biological rhythm was evaluated using the BRIAN. Disease activity was determined by the Disease Activity Score in 28 joints in RA patients.

Results: The BRIAN total score and sleep, activity, social rhythm and eating pattern scores were higher in patients with RA than in controls (BRIAN scale total score-44.8 \pm 8.6 vs $25.76 \pm 5.86$ $(p<0.001)$, sleep score $14.2 \pm 3.0$ vs $8.32 \pm 1.48(p<0.001)$, activity score $14.67 \pm 2.38$ vs $6.21 \pm 2.92(p<0.001)$, social score $8.68 \pm 1.33$ vs $6.64 \pm 1.48(p<0.001)$ and eating score $9.65 \pm 2.75$ vs $5.83 \pm 1.11$ $(p<0.001)$. A positive correlation was found between the Disease Activity Score-28 and BRIAN total score $(p=0.041, r=0.224)$.

Conclusion: RA may affect sleep patterns, activities of daily living and eating habits. RA patients should be evaluated in this respect and evaluation of patients with RA should include the circadian rhythm.

Keywords: Rheumatoid arthritis, biological rhythm, biological rhythms interview for assessment in neuropsychiatry scale
Öz

Amaç: Bu çalışmada romatoid artrit (RA) hastalarında biyolojik ritmi Biyolojik Ritim Görüşme Değerlendirme Anketi (BRIAN) ile değerlendirmeyi amaçladık.

Yöntemler: Çalışmamıza 85 RA hastası ve 85 sağlıklı kontrol dahil edildi. Biyolojik ritmi BRIAN ile değerlendirdik. Hastalık aktivitesi hastalık aktivite skoru 28 ile belirlendi.

Bulgular: RA'lı hastalarda uyku, aktivite, sosyal ritim, yeme düzeni ve toplam puan kontrol grubuna göre daha yüksekti (BRIAN toplam puanı $44,8 \pm 8,6$ vs $25,76 \pm 5,86(p<0,001)$, uyku puanı $14,2 \pm 3,0$ ve $8,32 \pm 1,48(p<0,001)$, aktivite puanı $14,67 \pm 2,38$ vs $6,21 \pm 2,92(p<0,001)$, sosyal ritim puanı $8,68 \pm 1,33$ vs $6,64 \pm 1,48$ $(p<0,001)$ ve yeme puanı $9,65 \pm 2,75$ vs $5,83 \pm 1,11(p<0,001)$ idi. Hastalık aktivite skoru 28 ile BRIAN arasında pozitif korelasyon saptadık ( $p=0,041, r=0,224)$.

Sonuç: RA hastalarının uyku patternleri, günlük yaşam aktiviteleri ve yeme alışkanlıkları etkilenebilir. RA hastaları bu açıdan değerlendirilmeli ve bu hastaların değerlendirmeleri sirkadiyen ritmi içermelidir.

Anahtar Sözcükler: Romatoid artrit, biyolojik ritim, biyolojik ritim görüşmesi nöropsikiyatri ölçeği
Address for Correspondence/Yazışma Adresi: Betül Sargın, Adnan Menderes University Faculty of Medicine, Department of Physical Medicine and Rehabilitation and Rheumatology, Aydın, Turkey Phone: +90 2562259287 E-mail: betul.cakir@yahoo.com ORCID: orcid.org/0000-0002-9463-8413 Received/Geliş Tarihi: 28 April 2019 Accepted/Kabul Tarihi: 22 October 2019
${ }^{0}$ Copyright 2020 by The Medical Bulletin of istanbul Haseki Training and Research Hospital The Medical Bulletin of Haseki published by Galenos Yayınevi. ${ }^{\top}$ Telif Hakkı 2020 istanbul Haseki Eğitim ve Araştıma Hastanesi Haseki Tıp Bülteni, Galenos Yayınevi tarafından yayınlanmıştır. 


\section{Introduction}

Rheumatoid arthritis (RA) is a chronic systemic and autoimmune disease (1). Morning stiffness as RA symptom follows the circadian pattern. Severity of RA symptoms is related to morning stiffness. Morning stiffness and severity of RA symptoms have been found to be associated with circadian rhytm (2).

"Circadian" is defined as the period of physiological function and behavior of the organism in about 24 hours. This rhythm involves various physiological functions such as sleep/wake cycle, body temperature regulation, hormone secretion, proliferation of cells and gastrointestinal function (3). Biological, psychological and social conditions can affect the circadian rhythm. This rhythm has been investigated previously in patients with bipolar disorder (4-5) and inflammatory rheumatic diseases such as polymyalgia rheumatica (PMR), ankylosing spondylitis (AS) (6) and fibromyalgia syndrome (7). The symptoms observed in patients with RA and the severity of these symptoms are related with the circadian rhythm. Diurnal variations of hormones and cytokine concentrations in RA have been described (2-3,8-13).

In our study, we compared sleep, activity, eating and social functions between RA patients and healthy controls. The primary aim of our study was to show that whether RA patients have a subjective circadian rhythm disturbance as assessed by the Biological Rhythms Interview of Assessment in Neuropsychiatry (BRIAN). To the authors' knowledge, this is the first study which evaluated biological rhythm using the BRIAN in RA patients.

\section{Methods}

This study was approved by the Ethics Committee of Adnan Menderes University (approval no: 2017-1122) and carried out from May 2017 to October 2017. All participants provided written informed consent.

Eighty-five RA patients and 85 healthy controls were included in our study. All RA patients were diagnosed according to the American College of Rheumatology/ European League Against Rheumatism (ACR/EULAR) criteria (14). Healthy controls were age- and gendermatched with RA patients.

Demographic characteristics of the patients were recorded. Disease activity was determined by the Disease Activity Score in 28 joints (DAS28). A value of higher than 5.1 was considered active disease (15). The biological rhythm was evaluated using the BRIAN. The BRIAN questionnaire we used is an 18-item selfreport questionnaire. It evaluates four domains i.e sleep, activity, social rhythm and eating pattern. All items are rated from 1 (no difficulty) to 4 (severe difficulty) and the total score ranges from 18 to 72 with the higher score greater biological rhythm disturbance (16).

Inclusion criteria were age over 18 years and diagnosis of RA established according to the ACR/EULAR criteria. Inclusion criteria for age- and gender-matched healthy controls were age over 18 years, no health problems and drug use. Exclusion criteria for RA patients and healthy controls were as follows: pregnancy, lactation, any infection or malignancy, presence of comorbidities such as Diabetes Mellitus, asthma, hepatic, renal, vascular and cardiac diseases, hypertension, chronic obstructive pulmonary disease, use of glucocorticosteroids, selective serotonin reuptake inhibitors and use of drugs which may cause psychiatric disorders. Also, smokers were excluded from the study.

\section{Statistical Analysis}

Analysis of the data was performed using the Statistical Package for the Social Sciences (SPSS) version 19.0 software. The Kolmogorov-Smirnov test was used to determine whether the quantitative variables were normally distributed or not. The independent samples t-test was applied to compare the groups for normally distributed variables and the Mann-Whitney $U$ test for the non-normally distributed variables. The relationship between quantitative variables was examined by Pearson's correlation coefficient. The dependence between qualitative variables was determined by Pearson's chisquare test. Descriptive statistics for quantitative variables were given as mean \pm standard deviation for normally distributed variables and as median (25th-75th percentile) for non-normally distributed variables. Descriptive statistics for qualitative variables were given as frequency (\%). A $p$ value of less than 0.05 was considered statistically significant.

\section{Results}

A total of 85 RA patients (20 males and 65 females) were included in the study. The mean age of the RA patients and controls was $56.48 \pm 9$ years and $56.00 \pm 15.47$, respectively. The disease duration was $50.6 \pm 28.6$ months. All the RA patients were receiving disease-modifying antirheumatic drugs. There was no statistically significant difference between the groups in terms of demographic features (age and gender), biochemical parameters, renal function levels and inflammatory markers $(p>0.05)$. The demographic features and laboratory parameters are shown in Table 1.

The BRIAN total, sleep, activity, social rhythm and eating pattern scores were higher in patients with RA than in controls (BRIAN total scores $44.8 \pm 8.6$ vs $25.76 \pm 5.86$ $(p<0.001)$, sleep score $14.2 \pm 3.0$ vs $8.32 \pm 1.48(p<0.001)$, activity score $14.67 \pm 2.38$ vs $6.21 \pm 2.92(p<0.001)$, social 
score $8.68 \pm 1.33$ vs $6.64 \pm 1.48(p<0.001)$ and eating score $9.65 \pm 2.75$ vs $5.83 \pm 1.11(p<0.001)$ (Table 2$)$. The mean DAS28 score was $3.9 \pm 1.0$ in RA patients and a positive correlation was found between DAS-28 score and BRIAN total score $(p=0.041, r=0.224)$.

\section{Discussion}

The biological rhythm has a regular periodicity of physiological or behavioral expression. The biological rhythm includes hormonal secretion and eating patterns as a result of the interaction between endogenous (hormones) and exogenous (temperature) factors (5). The higher BRIAN total, sleep, activity, social rhythm and eating pattern scores in RA patients may be associated with abnormalities of biological factors such as hormones and metabolism. There is a fifth domain which is not included in total score and provides a measure of chronotype (16).

\begin{tabular}{|c|c|c|}
\hline & $\begin{array}{l}\text { Rheumatoid } \\
\text { arthritis }(n=85)\end{array}$ & $\begin{array}{l}\text { Healthy group } \\
(n=85)\end{array}$ \\
\hline Age (years) (mean \pm SD) & $56.48 \pm 9.34$ & $56.00 \pm 15.47$ \\
\hline \multicolumn{3}{|l|}{ Gender } \\
\hline Male, n (\%) & $20(23.5)$ & $20(23.5)$ \\
\hline Female, n (\%) & $65(76.5)$ & $65(76.5)$ \\
\hline $\begin{array}{l}\text { Disease duration (months) } \\
\text { (mean } \pm \mathrm{SD})\end{array}$ & $50.6 \pm 28.6$ & - \\
\hline \multicolumn{3}{|l|}{ Medication } \\
\hline Convantional DMARDs, (n) & 85 & - \\
\hline Biological DMARDs, (n) & 0 & - \\
\hline $\operatorname{ALT}(U / L)$ & $19.0 \pm 8.6$ & $20.0 \pm 8.8$ \\
\hline Creatinine (mg/dL) & $0.77 \pm 1.01$ & $0.75 \pm 1.08$ \\
\hline $\operatorname{ESR}(\mathrm{mm} / \mathrm{h})($ mean $\pm \mathrm{SD})$ & $22.25 \pm 11.01$ & $20.82 \pm 11.08$ \\
\hline $\operatorname{CRP}(\mathrm{mg} / \mathrm{L})($ mean $\pm \mathrm{SD})$ & $5.83 \pm 15.95$ & $5.30 \pm 7.72$ \\
\hline \multicolumn{3}{|c|}{$\begin{array}{l}\text { SD: Standard deviation; RA: Rheumatoid arthritis; DMARDs: Disease modifying } \\
\text { anti-rheumatic drugs; ALT: Alanine aminotransferase; ESR: Erythrocyte } \\
\text { sedimentation rate; CRP: C-reactive protein }\end{array}$} \\
\hline
\end{tabular}

Table 2. Comparison of Biological Rhythms Interview of Assessment in Neuropsychiatry in patients with rheumatoid arthritis and healthy controls

\begin{tabular}{|l|l|l|l|}
\hline & $\begin{array}{l}\text { RA group } \\
(\mathbf{n}=85)\end{array}$ & $\begin{array}{l}\text { Healthy group } \\
(\mathbf{n}=85)\end{array}$ & $\mathbf{p}$ \\
\hline $\begin{array}{l}\text { BRIAN total } \\
\text { (mean } \pm \text { SD) }\end{array}$ & $44.8 \pm 8.6$ & $25.76 \pm 5.86$ & $<0.001$ \\
\hline Sleep (mean \pm SD) & $14.2 \pm 3.0$ & $8.32 \pm 1.48$ & $<0.001$ \\
\hline Activity (mean \pm SD) & $14.67 \pm 2.38$ & $6.21 \pm 2.92$ & $<0.001$ \\
\hline Social (mean \pm SD) & $8.68 \pm 1.33$ & $6.64 \pm 1.48$ & $<0.001$ \\
\hline Eating (mean \pm SD) & $9.65 \pm 2.75$ & $5.83 \pm 1.11$ & $<0.001$ \\
\hline
\end{tabular}

RA: Rheumatoid arthritis; BRIAN: Biological Rhythms Interview of Assessment in Neuropsychiatry, SD: Standard deviation
Aydemir et al. (17) performed the validity and reliability of the Turkish version of the BRIAN. It has been previously used in FMS (4), bipolar disorder (6-7) and in all disorders affected by biological and daily cyclic rhythm. We used the BRIAN due to the fact that it contains all biological rhythm variables in addition to sleep patterns when we compared with DAS28 (16). The scatter plot between BRIAN total score and DAS28 is given in Graphic 1. However, there was a weak correlation between DAS28 and BRIAN total score $(p=0.041, r=0.251)$.

Biological rhythm was evaluated in 82 fibromyalgia (FMS) patients and 82 controls by Ucar et al. (7). In this study, the BRIAN was used to assess the disturbances in biological rhythms. BRIAN total, sleep, activity, social, and eating scores were found to be higher in FM patients than in the controls. In our study, we found higher BRIAN total, sleep, activity, social rhythm and eating pattern scores in RA patients compared to the control group. Cutolo et al. (18) have supported the role of cytokines, hormones and circadian rhythm in PMR. Also, the circadian rhythm was defined in patients with AS. Hart et al. (19) described the first precise clinical descriptions of inflammatory back pain. Later, Spies et al. (6) reported the association between pain, stiffness and circadian rhythm in AS patients.

High inflammatory activity of RA accompanied by severe disturbance of the circadian rhythm has been reported (8). Joint swelling, stiffness, and pain are the main clinical symptoms of RA. These symptoms show a circadian variation (2). This variation is explained by proinflammatory cytokine and hormones (20). Gibbs and Ray (2) reported an association between RA pathology with the circadian clock. The circadian clock regulates the expression and activity of several genes. These genes, melatonin,

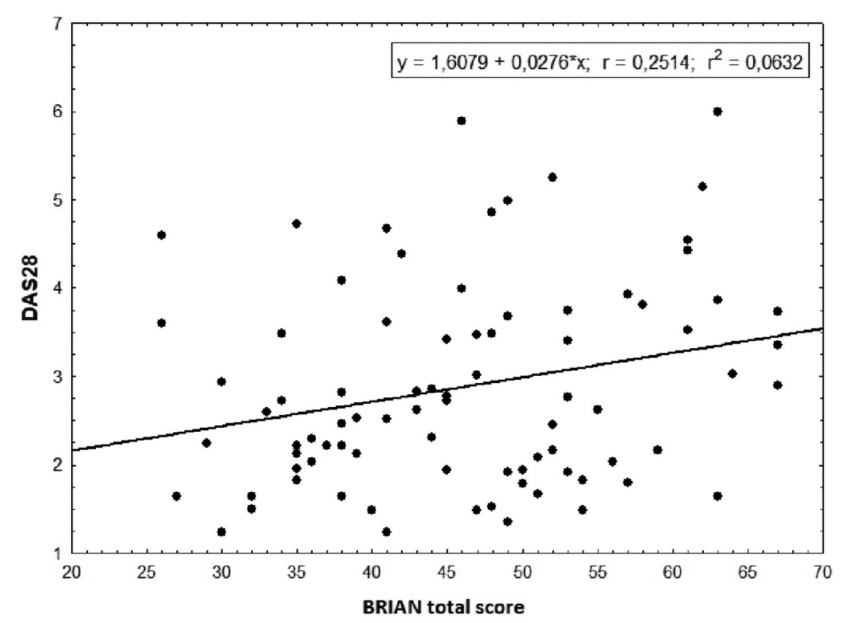

Graphic 1. The scatter-plot between BRIAN total score and DAS28

BRIAN: Biological Rhythms Interview of Assessment in Neuropsychiatry, DAS28: Disease Activity Score in 28 joints 
and glucocorticoids act as circadian agents. Cortisol and melatonin regulate circadian cytokine production in RA patients (10). Arvidson et al. (9) reported that the diurnal variation of IL-6 might explain the circadian rhythm of RA. The circadian pattern of various cytokines and hormones in RA suggests a new treatment paradigm (13).

\section{Conclusion}

As a result of our study, we found higher scores of the BRIAN total, sleep, activity, social rhythm and eating patterns in RA patients compared to that in healthy group. Circadian disturbance may be a consequence of the disease rather than the disease activity itself in RA patients. Sleep patterns, daily living activities, and eating habits of RA patients may be affected by circadian rhythm. Thus, RA patients should be evaluated in this respect and evaluation of RA patients should include the circadian rhythm. And a regression in disease activity with treatment may result in improvement in BRAIN scores including sleep score, activity score, social score, and eating score.

\section{Authorship Contributions}

Concept: B.S. Design: B.S. Data Collection or Processing: B.S. Analysis or Interpretation: B.S., G.G. Literature Search: B.S., G.G. Writing: B.S., G.G.

Conflict of Interest: No conflict of interest was declared by the authors.

Financial Disclosure: The authors declared that this study received no financial support.

\section{References}

1. Guo Q, Wang Y, Xu D, Nossent J, Pavlos NJ, Xu J. Rheumatoid arthritis:pathological mechanisms and modern pharmacologic therapies. Bone Res 2018;6:15.

2. Gibbs JE, Ray DW. The role of the circadian arthritisclock inrheumatoidarthritis. Arthritis Res Ther 2013;15:205.

3. Yoshida K, Hashimoto T, Sakai Y, Hashiramoto A. Involvement of the circadian rhythmand inflammatory cytokines in the pathogenesis of rheumatoid arthritis. J Immunol Res 2014;2014:282495

4. Cardoso TA, Campos MT, Reyes AN, et al. Biological rhythmandbipolardisorder:twelve-month follow-up of a randomizedclinical trial. J Nerv Ment Dis 2015;203:792-7.

5. Duarte FA, Cardoso TA, Campos MT, et al. Biological rhythms in bipolar and depressive disorders:A community study with drug-naive young adults. J Affect Disord 2015;186:145-8.

6. Spies CM, Cutolo M, Straub RH, Burmester GR, Buttgereit F. More night thanday-circadianrhythmsinpolymyalgia rheumatic andankylosingspondylitis. J Rheumatol 2010;37:894-9.
7. Ucar M, Sarp Ü, Gül Al, et al.Analysingbiological rhythmsinfibromyalgia syndrome. West Indian Med J 2015;64:241-4.

8. Neeck G, Federlin K, Graef V, Rusch D, Schmidt KL. Circadian rhythm of cortisol and corticotropin (ACTH) in patients with rheumatoid arthritis in relation to inflammatory activity. Z Rheumatol 1987;46:53-8.

9. Arvidson NG, Gudbjörnsson B, Elfman L, Rydén AC, Tötterman TH, Hällgren R. Circadianrhythmof serum interleukin-6 inrheumatoid arthritis. Ann Rheum Dis 1994;53:521-4.

10. Cutolo M, Seriolo B, Craviotto C, Pizzorni C, Sulli A. Circadian rhythms in RA. Ann Rheum Dis 2003;62:593-6.

11. Johannsdottir K, Gudbjornsson B. Diurnal rhythm of cytokines in rheumatoid arthritis may be reflected in vitrocultures of collected mononuclearcells. Clin Exp Rheumatol 2008,26:969.

12. Cutolo M. Rheumatoid arthritis:circadian and circannual rhythmsinRA. Nat Rev Rheumatol 2011;7:500-2.

13. Haus E, Sackett-Lundeen L, Smolensky M. Rheumatoid arthritis:Circadian rhythms in disease activity, signs and symptoms, and rationale for chronotherapy with corticosteroids and other medications. Bull Nyu Hosp Jt Dis 2012;70 Suppl 1:3-10.

14. Aletaha D, Neogi T, Silman AJ, et al. 2010 Rheumatoid arthritis classification criteria: an American College of Rheumatology/ European League Against Rheumatism collaborative initiative. Arthritis Rheum 2010;62:2569-81.

15. Fransen J, van Riel PL. The Disease Activity Score and the EULAR response criteria. Rheum Dis Clin North Am 2009;35:745-57.

16. Giglio LM, Magalhães PV, Andreazza AC, et al. Development and use of abiological rhythm interview. J Affect Disord 2009;118:161-5.

17. Aydemir O, Akkaya C, Altınbaş K, et al. Reliability and validity of Turkish version of Biological Rhythms Interview of Assessment in Neuropsychiatry. Anadolu Psikiyatri Derg 2012;13:256-61.

18. Cutolo M, Straub RH, Foppiani L, et al. Adrenal gland hypofunction in active polymyalgia rheumatica.Effect of glucocorticoid treatment on adrenal hormones and interleukin 6. J Rheumatol 2002;29:748-56.

19. Hart FD, Robinson KC, Allchin FM, MacLagan NF. Ankylosing spondylitis. Q J Med 1949;18:217-34.

20. Perry MG, Kırwan JR, Jessop DS, Hunt LP. Overnight variations in cortisol,interleukin 6, tumour necrosis factor alpha and other cytokines in people with rheumatoid arthritis. Ann Rheum Dis 2009;68:63-8. 